\title{
From the Acting Chairman of Medicine
}

\author{
Geno Merli \\ Thomas Jefferson University, Geno.Merli@jefferson.edu
}

Follow this and additional works at: https://jdc.jefferson.edu/tmf

\section{Let us know how access to this document benefits you}

\author{
Recommended Citation \\ Merli, Geno (2001) "From the Acting Chairman of Medicine," The Medicine Forum: Vol. 3 , Article 2. \\ DOI: https://doi.org/10.29046/TMF.003.001 \\ Available at: https://jdc.jefferson.edu/tmf/vol3/iss1/2
}

This Article is brought to you for free and open access by the Jefferson Digital Commons. The Jefferson Digital Commons is a service of Thomas Jefferson University's Center for Teaching and Learning (CTL). The Commons is a showcase for Jefferson books and journals, peer-reviewed scholarly publications, unique historical collections from the University archives, and teaching tools. The Jefferson Digital Commons allows researchers and interested readers anywhere in the world to learn about and keep up to date with Jefferson scholarship. This article has been accepted for inclusion in The Medicine Forum by an authorized administrator of the Jefferson Digital Commons. For more information, please contact: JeffersonDigitalCommons@jefferson.edu. 
Merli: From the Acting Chairman of Medicine

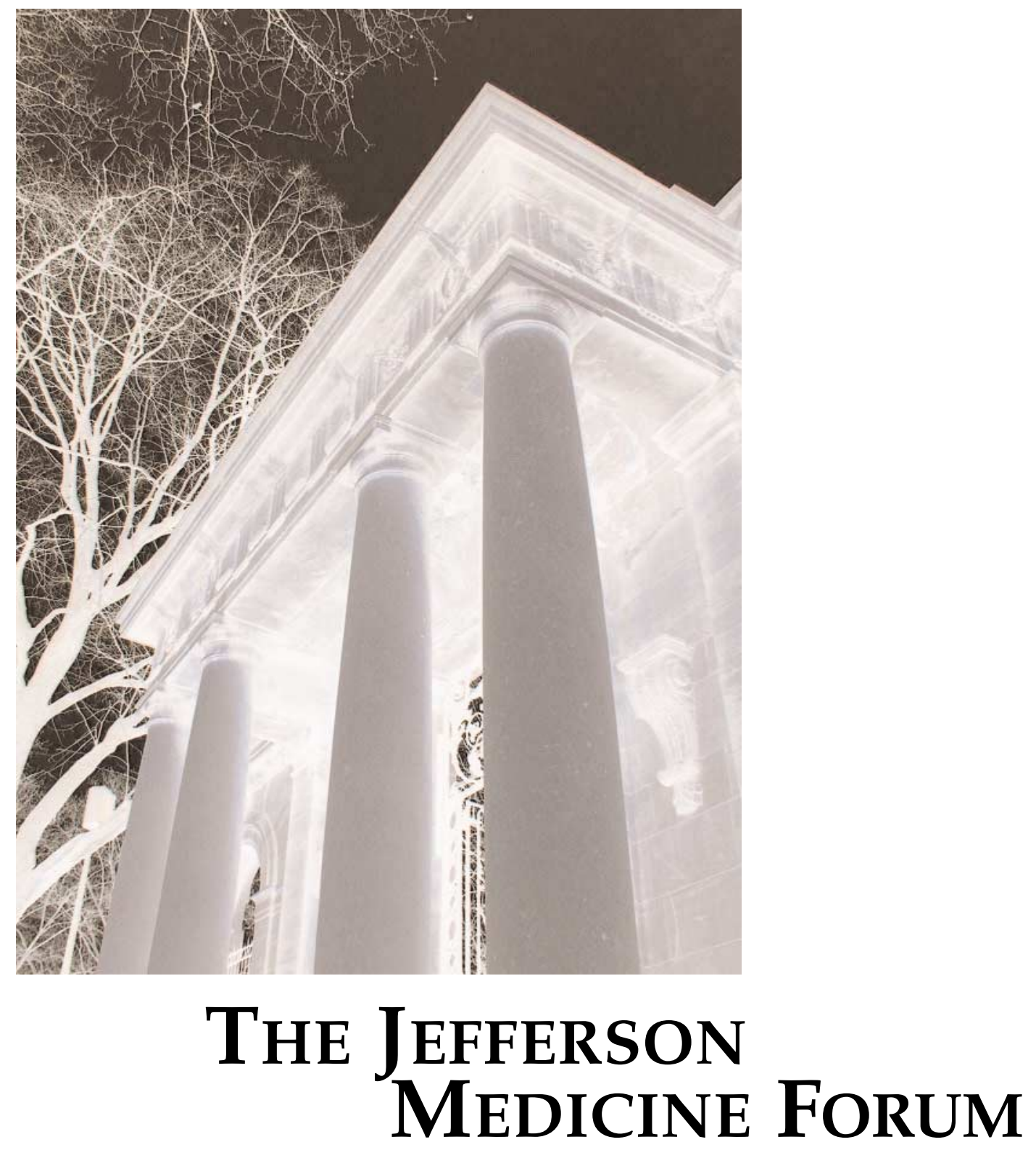


Q he Jefferson Forum has become an important part of the scholarly activities of our medical residency. It reflects the commitment, dedication, and enthusiasm of our residents toward furthering medical knowledge throught their observations and studies.

This third edition of the Jefferson Forum will be another volume attesting to the excellent editorial work of our medical residents and the Forum's staff.

I am proud to be part of such an outstanding medicine residency program.

Geno Merli, MD

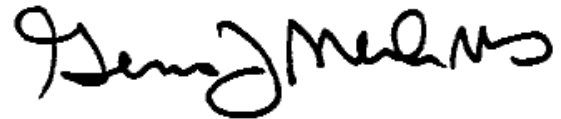

Acting Chairman of Medicine

Editor's Statement

\%rice the journal published and written by Jefferson Internal Medicine residents. In this issue, we are pleased to share with you case presentations, artistic works, reviews, and even original research. With this journal, we hope to engender the academic spirit of the Jefferson Community.

Thanks to all our contributors. We recognize and appreciate your involvement. We hope you enjoy this issue, and look forward to future submissions.

Rajani Dinavahi, MD

David Hong, MD

Elizabeth Cartwright, MD

\section{We gratefully acknowledge Bayer Pharmaceutical for providing an unrestricted} educational grant to support this journal. 